DOI: https://doi.org/10.11144/Javeriana.upsy18-5.pbai

\title{
Psychology in Brazilian Assistance to the Insane: First Half of the 20th Century*
}

\section{Psicología en la Asistencia brasileña a los insanos en la primera mitad} del siglo XX

Date received: 05 February 2019 | Date accepted: 30 October 2019

\author{
Cristiana Facchinetti \\ Fundação Oswaldo Cruz, Brasil \\ ORCID: http://orcid.org/0000-0003-4879-0307 \\ Ana Maria Jacó-Vilela ${ }^{\mathrm{a}}$ \\ Universidade do Estado do Rio de Janeiro, Brasil \\ ORCID: http://orcid.org/0000-0002-0728-8700
}

a Correspondence author. Email:
jaco.ana@gmail.com

How to cite: Facchinetti, C., \& Jacó-Vilela, A. M. (2019). Psychology in Brazilian assistance to the insane: First half of the 20th century. Universitas Psychologica, 18(5), 1-15. https://doi.org/10.11144/Jav eriana.upsy18-5.pbai

\begin{abstract}
This paper provides an overview on the history of the earliest applications of psychological practices in the two main mental institutions linked to the Assistance for Psychopaths in Rio de Janeiro, Brazil, in the beginning of the $20^{\text {th }}$ Century. This encompassed a range of clinical practices that employed psychological techniques and tools thought as having a curative effect on the causes or symptoms of mental illness. Mental hygiene doctors used those techniques as well, with the biopolitical goal of averting illness and any consequent risk and social danger. The techniques are analyzed in their relation to the modernization project of Brazilian nation and to the problem of what was then understood as its "degenerated population". The main objective of the paper is to investigate the role of Psychology in Brazil in the early $20^{\text {th }}$ Century. The results appoint an effective interrelation between the raise of scientific legitimacy of Psychological knowledge and technology and the integration of Psychiatry within different nation's modernization projects.

Keywords

assistance to alienated; history of psychology; psychological measurement; modernization project; mental hygiene.
\end{abstract}

\section{RESUMEN}

Este documento proporciona una visión general de la historia de las primeras aplicaciones de las prácticas psicológicas en las dos principales instituciones mentales vinculadas a la Asistencia para Psicópatas en Río de Janeiro, Brasil, a principios del siglo XX. Esto abarcó un rango de prácticas clínicas que emplearon técnicas y herramientas psicológicas comprendidas como portadoras de un efecto curativo en las causas o síntomas de la enfermedad mental. Los médicos de higiene mental también utilizaron esas técnicas, con el objetivo biopolítico de evitar enfermedades y cualquier consiguiente riesgo o peligro social. Las técnicas analizadas se consideran en relación con el proyecto de modernización de la nación brasileña y con el problema de lo que se entendió entonces como su "población degenerada". El objetivo principal es investigar el lugar que ocupa la psicología en el Brasil del inicio del siglo. Los resultados señalan una interrelación efectiva entre el aumento de la legitimidad científica del 
conocimiento psicológico y de la tecnología locales y la integración de la psiquiatría en diversos proyectos de modernización de la nación.

Palabras clave

asistencia a alienados; historia de la psicología; medida psicológica; proyecto de modernización; higiene mental.

This paper provides an overview on the history of the earliest applications of psychological practices in Brazil. These encompass a range of practices in the health care for the mentally ill that employed psychological techniques and tools with the intent of having a curative effect on the causes or symptoms of mental illness, by eliminating or inhibiting the pathological impulses stemming from an individual's condition (Shamdasani, 2005). Mental hygiene doctors used those techniques as well, with the goal of averting illness and any consequent individual or collective danger.

The narrative focuses on two of the main institutions linked to the Assistance for Psychopaths ${ }^{[1]}$ : the National Hospice for the Insane (Hospício Nacional de Alienados; hereafter named as HNA) ${ }^{[2]}$ and the Engenho de Dentro Colony (hereafter named as Colony).

[3] Both of them were located in the city of Rio de Janeiro, which was then the federal capital, the nation's center of cultural and political power. The HNA was constructed in 1852 far from the city, in an airy spot that afforded the tranquility recommended by French psychiatric theories. Students interested in Psychiatry took their training at the Observations Pavilion, the entryway into the asylum (Facchinetti \& Reis, 2014). As for the Colony, it began operating in 1911 in Rio de Janeiro's suburb to house the overflow of state-supported indigent women from the HNA (Sousa, Porto, \& Trigueiro, 2019). Since 1920, it started to offer family care service inspired on the model from the city of Geel, in Belgium (Venancio, 2011) and in 1921 turned out to be the headquarters of the Institute for Mental Prophylaxis [Instituto de Profilaxia Mental], which in 1923 developed as Brazilian Mental Hygiene League [Liga Brasileira de Higiene
Mental] (Facchinetti, Ribeiro, Chagas, \& Reis, 2010).

As to the time cut, this narrative is centered on the first half of the $20^{\text {th }}$ century, especially from the 1930s, when the federal government began to make more systematic efforts to nationalize health and education policies for the first time in the country (Facchinetti, 2015). During this endeavor, a new project to modernize society took shape, promising a future where the idea of progress resonated as well as the one of the lasting demise of degeneration (Cushman, 1995). This paper is about to explore the way Psychology took place within this modernizing process.

The study's theoretic and methodological framework is based on Huertas (2017) and seeks to construct a social history of the psy knowledges that enables one to think dialectically past and present, following the propositions of the "problem history". Another important reference is Dantes (2001), author that stresses the relations between the implementation of scientific activities and techniques and Brazilian political, economic and socio-cultural conditions of the period, calling attention to the role of science as a producer and product of its historical moment. Finally, with Mulberger (2017), the paper emphasizes the role of psychological testing in psychiatric institutions, a topic frequently erased from the memory of the psy knowledge, as shown elsewhere (Castro, Facchinetti, \& Portugal, 2018) ${ }^{[4]}$.

The study was carried out through the survey of primary literature sources, in special medical journals as the Archives of Legal Medicine and Identification [Arquivos de Medicina Legal e Identificação], Brazilian Archives of Mental Hygiene [Arquivos Brasileiros de Higiene Mental], Brazilian Archives of Psychiatry, Neurology and Legal Medicine [Arquivos Brasileiros de Psiquiatria, Neurologia e Medicina Legal], Bahia Medical Gazeta [Gazeta Médica da Bahia], Brazilian Archives of Psychiatry, Neurology and Related Sciences [Arquivos Brasileiros de Psiquiatria, Neurologia e Ciências Afins], Neurobiology and Proceedings of the Assistance to Psychopath [Neurobiologia e Anais da Assistência 
a Psicopatas]. Besides the primary sources, this work made also use of the authors' previous studies on the theme, as can be observed throughout the article. The texts selected from this mass of primary sources were later analyzed taking into consideration the proposed theoretical framework.

With the support of this mass of documents and the selected theoretical-methodological instruments, the analysis built a coherent narrative in which the country's historical context was articulated with the development of psychiatric science. In order to achieve this goal, the study organized the themes in subtitles as to offer new angles to the history of psychological knowledge, giving visibility to the emergence of its techniques and technologies. The text takes up the debate developed elsewhere (Facchinetti \& Muñoz, 2013) as to emphasize the lack of legitimacy Alienism faced in the end of $19^{\text {th }}$ century when confronted to the new scientific parameters of the biomedical sciences. It underlines how the demands for scientificity led Brazilian Mental Medicine to push aside French psychogenic theories in favor of German organicist Psychiatry. Hereafter, the paper articulates this shift with the expansion of experimental laboratories and psychological testing. Then, the authors seek to demonstrate how this operation allowed Psychiatry to get closer to the State nation projects, as coresponsible for the regeneration of its population.

\section{Biomedical sciences - new paradigms}

The psychological and scientific treatment of moral suffering began in Brazil in the first decades of the $19^{\text {th }}$ century (Silva, 2012) and found expression under an imperial decree that called for the construction of an asylum for the insane in Rio de Janeiro (Meyer, 2017). The building began operating in 1952, with 144 inpatients. Scientific specialization gradually installed itself during the first thirty years of the asylum, and through clashes and negotiations in face of the charitable aims of the nuns who administered it (Brandão, 1886).
While an ex-colony of Portugal, its intellectual life had strongly stifled. For the most part, members of the country's tiny intellectual elite studied law or medicine in Coimbra, Portugal, or Montpellier, France, while the rest of the population could barely read or write. As a result, French culture and science heavily influenced the Brazilian elite, as was the case throughout Latin America during the $19^{\text {th }}$ century (Klappenbach, 2006). There was something of an Italian influence as well, particularly in the beginning of the $20^{\text {th }}$ century, related to the association between madness and crime, via Camillo Sante de Sanctis (1862-1935) and Benigno Di Tullio (1896-1979), among others (Dias, 2015).

From the second half of the $19^{\text {th }}$ century on, evolutionism, materialism and the notion of progress began to constitute the theoretical basis for a civilized nation and its impasses. In the case of local Psychiatry, such theories were then articulated with ideas of mental and physical primitivism, and turned out to be the basis for the "racial issue" in Brazil. In fact, especially after the abolition (1888), the strong presence of African descent and miscegenation became the main justification for the backwardness of the country. The transformation of biological difference into justification for social inequality as proposed by French degenerationist Psychiatry - led to the conclusion that, with the type of population that inhabited Brazil, the goal of building a civilized nation like Europe was virtually impossible (Rodrigues, 1890).

After the chair of Psychiatric clinic and mental illness was created in 1881, interest in psychological knowledge grew even more, and many doctoral theses started to address the topic. [5] Wilhelm Wundt (1832-1920), Jean-Martin Charcot (1825-1893), Hippolyte Bernheim (1840-1919), Pierre Janet (1859-1947) and Alfred Binet (1857-1911) were some of the many authors that circulated in descriptions of the newest scientific mental theories (Stubbe, 2015, pp. 15-58).

But in the last years of the $19^{\text {th }}$ century, the German presence in Brazil also grew 
steadily as the two countries began cooperating in various realms: military, scientific, literary, and so on (Rinke, 1996). German medicine played a preponderant role in this relationship, shifting the balance of French influence on Psychiatry. In the 1870 s, the proposal of experimental medicine had spurred an 1879 reform in medical schools inspired on the German model. The goal of the reform had been to replace "the speculative, doctrinaire phase" of local medicine with a "truly scientific state," characterized by objectivity and by verifications measured with laboratory instruments (Sabóia, 1883, cited in Edler, 1996, p. 293). This change in theoretical framework triggered much controversy, but it was inescapable. By the mid-1880s, especially after Brazil headed towards Republic, proclaimed in 1889, experimental medicine ruled the day (Edler, 1992). In tune with these times, mental medicine began looking for new theoretical formulations on mental disease. French psychogenic theories were very much pushed aside in favor of German Psychiatry's organicist and etiological theories (Muñoz, 2015). Observation and controlled laboratory testing became central in the analysis of mental illnesses and their treatments. Within this new framework, conjoining data from anatomical pathology, medical practice, and experimental psychology became indispensable (Portocarrero, 2002, pp. 61-63; Cunningham, 1992).

Also, as a result, psychological tests and psychiatric concepts began to intertwine with society's modernization projects (Cushman, 1995) and physicians began to urge the State to foster the foundation of institutes and laboratories. Psychiatrists lent their voices to the chorus of doctors calling for labs. In 1902, for example, psychiatrist Juliano Moreira (1873-1933) visited several hospitals throughout Brazil after returning from his studies in Germany (Jacobina \& Gelman, 2008, p. 1078). After his visits, he began a campaign for laboratories equipped with "the machinery of scientific labor" for the use not only of psychiatric asylums (Moreira, 1902b) but also of all public hospitals and medical schools in the country (Moreira, 1902a).

It was during the growing importance of experimentalism that the Assistance agency was reorganized (Meyer, 2017). Dr. Juliano Moreira became the HNA director, a post he held until 1930.

\section{Psychology Lab}

Soon after taking charge of the asylum, in 1903, Juliano Moreira reorganized it and made several structural reforms. He maintained inpatients separation by gender and social class ${ }^{[6]}$ as introduced under direction of Dr. Teixeira Brandão (1854-1921) — while created new divisions, wards, and pavilions to house patients displaying specific diagnostics. ${ }^{[7]}$

The organization of its laboratories was also one of his priorities. In addition to refurbishing the histo-chemistry lab, he had an anatomical pathology laboratory installed (Facchinetti \& Muñoz, 2013), as well as the Nissl Laboratory for the neuropathology and histopathology of the nervous system. These laboratories enabled the application of routine sub occipital puncture and complete exam of the liquor to identify cases of neuro syphilis (Ramos \& Geremias, 2014). From this period on, blood tests like cytology, the Wassermann reaction, and the four reactions of Nonne became a protocol, present on almost all patient charts. The doctors believed these exams provided reliable information for the diagnosis and efficacious treatment of syphilitic diseases of the central nervous system (Pires \& Luz, 1931, p. $3)$.

Psychiatry's reliance on Kraepelin's formulations also allowed the field to contradict racialist theories and theories about hierarchies among peoples (Moreira, 1907, p. 102), a line of thought that had pervaded alienist theses in the late $19^{\text {th }}$ century (Oda, 2000). As he put it, "in the struggle against nervous and mental degeneration, the enemies are alcoholism, syphilis, verminosis, sanitary and adverse educational conditions"; thus, mental hygiene work on behalf of people should 
not "be affected by ridiculous color or caste prejudices" (Moreira, 1922, p. 225).

Instead of attributing mental illness to race and race mixing, the HNA started assigning its etiology to neurological and bacteriological damage. With this outlook embraced, local Psychiatry could join with the national public health movement, which held that people's poor health and their lack of education were to blame for the country's widespread degeneration (Moreira, 1925).

Regarding experimental psychology, the first experimental psychology laboratory in Brazil was set up in 1897 at the HNA (Lourenço Filho, 2004). Thanks to this lab, Brazil produced its first medical thesis in experimental psychology, entitled "Length of elementary psychic acts in the insane" [Duração dos atos psíquicos elementares nos alienado] (Roxo, 1901). In his thesis, Roxo used the "psychotronic" of Gabriele Buccola, one of the first Italian psychiatrists interested in experimental and physiological psychology. Roxo presented the stimuli through the psychotronic and used a Hipp chronoscope to measure for response. With those instruments, he devoted himself to analyze reaction time of patients confined to the HNA and compared it to that of "healthy" people. He also made comparisons between the different types of HNA's population, seeking to present objective data to support his research.: children versus adults, women versus men, and whites versus blacks, as well as individuals with different diagnoses. At the end of his measurements, Roxo stated that the alienated presented longer duration of elementary psychic acts than healthy individuals. The student concluded that the longer the reaction time, the greater the proximity of the individual to some morbid type of alienation. With these results, pointed out the importance of psychological experimental techniques to psychiatric clinic. ${ }^{[8]}$

But the Experimental Psychology Laboratory (GPE) was officially inaugurated in 1907 and consisted of a room with psychological instruments that already existed in the HNA and others that Juliano Moreira commissioned directly from Europe to carry out the reform of the lab. (Penna, 1989; Mathias, 2016). [9] On the occasion, Maurício Campos de Medeiros (1885-1966), whose doctoral thesis was named "Methods in Psychology" (c.f. 1908) was put in charge of the Experimental Psychology Lab until 1925. With the new experimental support, mental exams of the insane began to include objective assessments based on increasingly sophisticated research instruments and technology. Psychiatrists measured attention using Bourdon's method or Ebbinghaus method or Toulouse; and speech and writing were evaluated through objective observations. According to contemporary reports by physicians, the activity of thinking became better understood thanks to the Marey pneumograph, which measured the patient's respiration to detect traces of excitement or depression (Medeiros, 1908, p. 32).

Besides intending to satisfy broad goals of basic science, the laboratory quickly became a widely used resource for establishing diagnostics in the National Hospice's Observatory Pavilion especially after Henrique Roxo, doctor of the institution and substitute Professor with chair at the Medicine School became chair of the Psychiatric Clinic, after the death of Teixeira Brandão (Mathias, 2016). His Manual of Psychiatry designated several of the tests used at the Chair for Clinical Psychiatry at the Faculty of Medicine for the study of the disturbances of the consciousness in relation to the association of ideas and to memory (Roxo, 1938). In fact, when describing the forms that the psychiatric intern had at hand for the diagnostic process, the Professor emphasized that after the clinical interview, "the psychology laboratory will be used in order to establish the clinical Psychometry of the patient" (Roxo, 1938, p. 76).

It is possible, however, to verify that the extensive use of tests and examinations was not a particular case. According to the sources investigated, it was possible to verify, for example, that Murillo de Campos, a medical officer of the Brazilian Army responsible for soldiers and officers confined at the HNA made use of the Ebbinghaus's memory and the BinetStanford Intelligence Scale test, as well as of 
several other psychological trials, to evaluate his inmates (Saturnino, 1930). Campos also employed psychogenic tests like Breuler-Jung word association, in which the subject responds to a stimulus word with another word that comes to mind (Campos, 1931).

The use of psychological tests, often associated with physiological, blood and cerebrospinal fluid exams, promoted Psychiatry into higher standards of scientificity. Certainly, its approach to general medicine generated greater trust from the authorities and the general public in its effectiveness (Carrara \& Carvalho, 2010). With the new technological instruments, it became possible to imagine the nation of the future oriented by the new experimental, Organicist Psychiatry. As Monteiro Lobato, an important intellectual of the period put it:

"Today we breathe easier. The laboratory has given us the argument we so eagerly sought. Grounded in it, we shall counter Le Bon's sociological condemnation with the higher voice of biology" (Lobato, 1956, p. 298).

\section{Civilizing the Brazilian people through experimental science}

When the Assistance for the Insane joined the public health movement and its educational and preventive drive, it made a shift from focusing solely on individual's neuropathology to the collective well being and its risks. There after Psychiatry has ceased to use psychological tests solely for the assessment of insane people and has begun to learn them in the general population. Several works (Costa, 1976; Carvalho, 1997; Engel, 2001; Boarini, 2003; Jacó-Vilela \& Silva, 2016) have already drawn attention to the central role of mental hygiene and the Brazilian League of Mental Hygiene (LBHM) for the circulation and legitimation of Brazilian psychiatric discourse in our country. According to them, as Reis (2000) would assert, the League constituted a formulation of a new and expanded project of social intervention of Psychiatry.

The mental doctors began to participate in broader debates on new solutions for the completely regeneration of the country. This "spectacular" future would be achieved through campaigns against venereal disease and abuse of alcohol; health campaigns against uncinariosis and other worms; measures to prevent the procreation "among perverted people" by the application of eugenic precepts; and by the use of scientific education in schools, among others (Moreira, 1925, p. 225).

To combine the preventive efforts and to give them the strength of an institution, Psychiatrists founded the Brazilian League of Mental Higiene (LBHM) in Rio de Janeiro in 1923, having doctor Gustavo Riedel (1887-1934) as its head (Boarini, 2018). The House of Representatives, by Decree No. 4,778 of December 27, 1923, recognized it as of public utility ${ }^{[10]}$. In 1925, the "program of technical work aimed at the prevention of nervous diseases" took action and LBHM inaugurated the Brazilian Archives of Mental Hygiene (Facchinetti, Cupello, \& Evangelista, 2010), its publication dedicated to the dissemination of hygiene principles, guiding "who wish to collaborate in the campaign for mental hygiene" so as to make it "the universal moral of tomorrow" (LBHM, 1925).

Educating the "primitive" Brazilian people constituted one of the League's main goals. Grounded in the tools of experimental psychology and in modern psychological theories, scientific education should be used "to instill a more refined moral formation in the masses" (Esposel, 1925, p. 105), transforming primitive Brazilians into people capable of rising to heights of citizenship unprecedented in this country (Russo, 2005) through evolution (PortoCarrero, 1933). In order to be able to do so, tests and apparatuses were adapted to Brazilian reality. In midst of active appropriation, a new concept of mental functioning conjoined the precepts of German Neuropsychiatry (Muñoz, 2015), and the one of Biotypology of Ernst Kretschmer (1888-1964), which secured a foothold in local Psychiatry, particularly in the 1940s (Dias, 2015). In Brazil, both theories were used to define humans according to their nature: heredity, constitution, and temperament were the main 
elements in defining an individual's personality, mental health, intelligence, and aptitude. As eugenicist Renato Kehl (1889-1974) put it, psychology had "abandoned philosophy" and moved into "new spheres with the advance of human genetics and proof of the role of internal secretion glands" (Kehl, 1941, p. 9). However, there was still a place for the environment, since these scientists believed that "external stimuli" could affect a person's constitution. The foundation for this lied in an individual's static hereditary traits (constitution) and in his dynamic traits (temperament), as well as in his reactive characteristics (emotional and volitional) (idem).

Mental hygiene doctors believed that most of the "primitive Brazilian" would evolve quicker with the aid of science, allowing them to imagine a time when the country would finally be fully hygienized and evolved. But for those constitutionally unfit to the needs of modernity, the new tools of the laboratory would also enable identification and isolation. Many League members argued that once these individuals had been identified, their reproductive rights should be restricted, either through the induced abortion of socially undesirable children or through sterilization (Facchinetti, 2015).

This outlook led to an increase in the number of laboratories serving educational purposes since they considered that they were vital to put forward the progressive school movement known as "New School" that is, student-centered teaching, which required that each pupil's aptitude and intelligence be ascertained. The first educational lab was precisely created by the LBHM. In the 1920s and early 1930s it had as its main function, to standardize psychological tests - such as Binet's, Toulouse - with and for use by Brazilian schoolchildren (Jacó-Vilela, 2014). The tests varied on memory fixation (Leme Lopes, 1930) and attention (Leme Lopes, 1932), among others, and were used in different situations (Leme Lopes \& Fialho, 1929). Central for the development of tests, these laboratories, however, relied very little on experimental apparatuses and much more on psychological testing, mainly to allow the professionals to group students into 'homogeneous classes' (idem).

\section{The Psychology Laboratory at the Engenho de Dentro Colony in Rio de Janeiro.}

Chief among the League psychological laboratories was the Psychology Laboratory at the Engenho de Dentro Colony in Rio de Janeiro. Gustavo Riedel helmed the Colony from 1918 until his death, in 1932, and he reorganized the institution and assigned it new tasks according to mental hygiene precepts. His interest in prevention prompted him to establish the Experimental Psychology Laboratory (Laboratório de Psicologia Experimental), [11] among other structures that targeted hygiene initiatives (Oliveira, 2004). The laboratory was in operation from 1923 to 1932, when it became the Psychology Institute (Instituto de Psicologia). Waclaw Radecki (1887-1953) [12] organized and directed the well-equipped new institute, with an abundance of material purchased in Leipzig and Paris (Centofanti, 1982).

According to Riedel (1925, p. 210), he first hired Radecki as director of the institute to initiate and spread the use of tests to screen and rank pupils, and the organization of classes based on psychological measurements of the students. However, Radecki saw a series of problems with lay usage of these tests:

"The tests (...) have, however, a capital defect, according to our opinion: they represent precisely a recipe ready to act, given by psychology to the hands of lay people who, as much in the application of the investigations as in the interpretation of the results, commit many errors resulting from the defects even of the method". (Radecki, 1925, p. 14)

In another piece of work at the same issue of the league's journal, Brazilian Archives of Mental Hygiene (Arquivos Brasileiros de Higiene Mental) written with his wife as second author, they recommended that educators based 
their analyses of children on observation. He offered a questionnaire to guide observations of pupils' basic mental processes, including sensory sensitivity, attention, discernment, memory, imagination, thinking, emotional life, and volition (Radecki \& Radecka, 1925). He further stated that psychological tests should only be applied by skilled professionals.

These measures were meant to boost the efficiency of both student classes and teachers (Wanderbroock \& Boarini, 2009). Another concern had to do more with the ideology of national identity: the psychological tests had to be tailored to "Brazilian intelligence" (Leme Lopes \& Fialho, 1929, p. 70). The Psychology Laboratory of the League was crucial on establishing a standard for the good / normal Brazilians (students) in terms of not acquired but innate skills. Tailoring the tests to Brazilians thus served to separate the wheat from the chaff and keep the "retarded" or "backward" students, who were by nature "unbalanced," from thwarting the development of the more "advanced" and thereby impeding the progress of the nation (Porto-Carrero, 1933, p. 49). Another important line of work involving children was Radecki's research on fatigue among child laborers (Lopes, 1925, p. 214; Radecki \& Radecka, 1925).

While Radecki's resistance to teachers' use of tests echoed, new uses were identified. The LBHM proposed that factories and the Army should also use intelligence tests to identify the "suitable place for the right worker," guided by scientific occupational selection. Radecki taught a course on the theme at the Army School of Social Work under the title Treaty of Psychology (Radecki, 1928/1929). Assistant of Édouard Claparède, Radecki was one of the few psychologists active in Brazil at that time, when those interested in psychology were still self-taught. Its presence shows how the Army was aware of theoretical novelties, especially if we link it to the creation, in the same year, of the School of Physical Education, where we find a strong presence of Psychology (Carvalho, 2012). Agnello Ubirajara da Rocha (1896-1984), Arauld da Silva Bretas (1881-1971) and Alberto Guilherme Moore (1860-1968), who were military physicians, worked with Radecki at the Psychology Laboratory of the Colony of Psychopaths of Engenho de Dentro (Centofanti, 1982). Alongside their interest, the presence of these medical military personnel in the Radecki-led Laboratory was due to their mission to conduct a health check on military pilot candidates for the Army Aviation Weapon, established in 1927 (Law. 5168, 1927). No wonder the Laboratory was included among establishments able to receive Military doctors (Army Bulletin No. 572 of January 10, 1930).

The League's efforts have been very successful, and its methods gained great social recognition. A decade after the creation of its laboratory, Psychology had gained ample space in society. No longer subsumed under the orders of education, Psychology of the second half of the 1940s had gained centrality in the fields of selection and professional orientation, in schools, in clinics, and parental orientation. In all these fields, psychological tests had become the privileged instrument for the performance of the new professional (Jacó-Vilela, 2012). As the editors of the Mental Hygiene Brazilian Archives focus on them,

"Those techniques, more than any other, will allow the expert to make a fair assessment of the normal mentalities, indispensable prior work to a number of specific applications of mental hygiene, in the strict sense, that is to say, concerning the healthy-minded individuals: vocational guidance, psychological selection of schoolchildren, mental health of schoolchildren workers, etc." (LBHM, 1930, p. 311).

\section{Final Considerations}

As we hope to have demonstrated, investigations into the history of techniques and technologies, sometimes overlooked by the historiography of psychological sciences, are very fruitful. The use of them as a historical source is an important entry into the process by which psychological knowledge was developed and institutionalized as practices in Brazil in the first half of the $20^{\text {th }}$ century. But this strategy 
enabled us more: to glance the history of psychological sciences as a chapter of the history of Brazil itself. In this regard, the results have sought to illuminate how psychologically oriented intellectuals and doctors conquered a privileged political position in Brazilian society and within Brazilian government administrations' agendas in the realm of social organization. Finally, the emphasis on tests and other technologies has brought to light some immaterial aspects of representations of modernity and scientificity of the social world, as well as the ones of appropriations, through which "a sense is historically produced and a meaning is differently constructed " (Chartier, 1990, p. 24) for understanding mental abnormality, treatment, and cure.

To demonstrate this, the article made a historical trajectory starting with the difficulties of Psychiatry to adjust to the parameters of general biomedical scientificity, in the last quarter of the XIX century. Another problem the XIX's intellectuals had to face was the question of race in midst of racialist theories after the Abolition of Slavery, an issue thought then as a major obstacle for Brazil to adjust to the "concert of civilized nations". As we have indicated, the racialist degenerative theory put a major limit on the participation of psychiatric discourses in these scientific and social impasses as well.

At the turn of the 20th century, Psychiatry came closer to the laboratory and to experimentation as a solution to increase its legitimacy. This epistemological shift was also reflected in the weakening of racialist theories and the entry of new scientific explanations from Bacteriology and Mental Hygiene that pointed then to political actions capable of changing the local population pattern. As to Psychiatry, psychological testing and experiments increased its social and scientific power, giving rise to psychological based systems of thought amid organicist mind theories. Accordingly, Psychology gained strength as discipline, slowly gaining importance among other fields of Psi knowledge that intersected with it.

In this context, psychiatrists and their laboratories began to build their identity as one of the main key players to change the nation. In this sense, Psychiatry began to support government efforts in a different way from what it did before. Although it continued to remove from society those abnormal individualities that, due to their dangerousness and risk of contagion, they believed that could degenerate society, it also began to play the role of preventing illness through Mental Hygiene. That way Psychiatrists began to be willing to participate in the efforts of social regeneration through aligning individuals to the environment with support of objective test results and other experimental exams. As they saw it, education, discipline, and medicine were tightly entwined, and doctors of the mind should be understood as the pillars of a new practice, one that could civilize Brazilians and adapt them to labor and learning. In short, it is possible to state that tests applications gained a great space at the time and was considered between scholars as an important instrument of modernization of Brazilian society.

Despite their importance, the studies established so far indicate that the period under study brought, at the same time, growing critical analysis of the value preventive psychiatric proposals, especially from the end of the Second World War on. In the same way and period, voices were condemning the "simplifying, misleading (claiming to be exact)" tendency of "modern psychotechnics," which used tests for everything (Pires, 1951, p. 135), and increasingly underscored the role of clinical practice in research and treatments of a moral nature. For these, psychotechnics were "much more tinsel than gold" (Pires, 1951, p. 135). We consider such findings to be extremely important, as they prevent us from thinking about a linear and evolutionary history of psychology, paving the way for discussions about discursive formations and scientific controversies in the history of technologies and technics. The limits of this introductory work, however, prevent the analysis from deepening in the critical position of the actors of the time, which is to be established in the next work on the subject. 


\section{References}

Boarini, M. L. (2003). Higiene e Raça como projetos: higienismo e eugenismo no Brasil. Maringá: EDUEM.

Boarini, M. L. (2018). Gustavo Kohler Riedel. Médicos que atuaram no Hospital Nacional de Alienados (blog). https://www.hpcs.bvsalud.org/wp-c ontent/uploads/2019/06/Riedel-Gustavo.p df

Brandão, J. C. T. (1886). Os Alienados no Brasil. Rio de Janeiro: Imprensa Nacional.

Campos, M. (1931). Tentativa de homicídio por octogenário displázico, eunucóide delirante. Archivos de Medicina Legal e Identificação, 1(1), 39-43.

Carrara, S., \& Carvalho, M. (2010). A sífilis e o aggiornamento do organicismo na psiquiatria brasileira: notas a uma lição do doutor Ulysses Vianna. História, Ciências, Saúde-Manguinhos, 17(2), 391-399. https://doi.org/10.1590/S0 104-59702010000600007

Carvalho, A. M. T. (1997). O elemento psychico no trabalho humano: a Liga Brasileira de Higiene Mental e o processo de produção discursiva do campo trabalho e higiene mental no Brasil entre 1925 e 1934 [The psychic element in human work: the Brazilian League of Mental Hygiene and the discursive production process of the field of work and mental hygiene in Brazil between 1925 and 1934] (Master's dissertation). Escola Nacional de Saúde Pública, Rio de Janeiro.

Carvalho, C. A. (2012). Psicologia do Esporte no Brasil: história e nuances de sua constituição [Sport Psychology in Brazil: history and nuances of its constitution] (Doctoral dissertation). Universidade do Estado do Rio de Janeiro, Programa de pós-Graduação em Psicologia Social, Rio de Janeiro.

Castro, A. C., Facchinetti, C., \& Portugal, F. (2018). Técnicas, saberes e práticas psicológicas na Primeira República (1889-1930) [Techniques, knowledge and psychological practices in the First Republic (1889-1930)]. Psicologia em Estudo (online),
23, 3-12. https://doi.org/10.4025/psicolestu d.v23i0.37446

Centofanti, R. (1982). Radecki e a Psicologia no Brasil [Radecki and Psychogy in Brazil]. Psicologia: Ciência e Profissão, 3(1), 2-50. https://doi.org/10.1590/S1414-98931 982000100001

Chartier, R. (1990). Por uma sociologia histórica das práticas culturais. In R. Chartier (Ed.), História Cultural: entre Práticas e Representações. Rio de Janeiro: Bertrand Brasil.

Costa, J. F. (1976). História da psiquiatria no Brasil: um corte ideológico. Rio de Janeiro: Garamond.

Cunningham, A. (1992). Transforming plague: the laboratory and the identity of infectious disease. In A. Cunningham (Ed.), The laboratory revolution in medicine (pp. 209-244). Cambridge: Cambridge University Press. https://doi.org/10.4324/97 81351219549-9

Cushman, P. (1995). Constructing the self, constructing America. A cultural history of psychotherapy. Massachusetts: Da Capo Press.

Dantes, M. A. M. (Org.) (2001). Espaços de Ciência no Brasil - 1800-1930. Rio de Janeiro: Ed. Fiocruz.

Dias, A. A. T. (2015). Arquivos de Ciências, Crimes e loucuras: Heitor Carrilho e o debate criminológico do Rio de Janeiro entre as décadas de 1920 e 1940 (Doctoral dissertation). Fundação Oswaldo Cruz, Rio de Janeiro. https://www.arca.fiocruz.br/han dle/icict/17767

Edler, F. C. (1992). As Reformas do Ensino Médico e a Profissionalização da Medicina na Corte do Rio de Janeiro 1854-1884 (Master's of Science thesis). Universidade de São Paulo, Brasil. http://caph.fflch.usp.br/node/4317

Engel, M. G. (2001). Os delírios da razão: médicos, loucos e hospícios (Rio de Janeiro, 1830-1930). Rio de Janeiro: Editora Fiocruz. https://doi.org/10.7476/97885754 12534

Esposel, F. (1925). Ideas Geraes. Trabalhos Originaes. Archivos Brasileiros de Hygiene 
Mental, 1(1), 101-8. Retrived from https:// www.old.ppi.uem.br/gephe/index.php/arqu ivos-digitalizados/14-sample-data-articles/8 5-arquivos-brasileiros-de-higiene-mental

Fabricio, A. L. C. (2009). A Assistência Psiquiátrica no contexto das políticas públicas de saúde (1930-1945) (Master's of Science thesis). Fundação Oswaldo Cruz, Rio de Janeiro. https://www.arca.fiocruz.br/handle /icict/6104

Facchinetti, C. (2011). Hospital Nacional de Psicopatas. In A. M. JacóVilela (Ed.), Dicionário Histórico de Instituições de Psicologia no Brasil (Vol. 1, pp. 250-252). Rio de Janeiro: Imago. http://pepsic.bvsalud.org/scielo.php $?$ script $=$ sci_arttext\&pid $=$ S1518-6148201 $100130001 \overline{4}$

Facchinetti, C. (2015). Júlio Pires Porto-Carrero: A psicanálise como ferramenta para a "Idade de Ouro" no Brasil. In G. Hochman; N. T. Lima (Org.), Médicos intérpretes do Brasil (Vol. 1, pp. 1-20). São Paulo: Hucitec. Facchinetti, C., \& Reis, C. S. (2014). O Hospício Nacional: arquitetura, política e população (1852-1902). In A. M. Jacó-Vilela \& F. T. Portugal (Orgs.), Clio-Psyché: Instituições, História, Psicologia (pp. 95-123). Rio de Janeiro: Outras Letras.

Facchinetti, C., \& Muñoz P. F. N. (2013). Emil Kraepelin na ciência psiquiátrica do Rio de Janeiro, 1903-1933. História, Ciências, Saúde-Manguinhos, 20(1), 239-62. https://doi.org/10.1590/S01 04-59702013000100013

Facchinetti, C., Ribeiro, A., Chagas, D. C., \& Reis, C. S. (2010). No labirinto das fontes do Hospício Nacional de Alienados. História, Ciências, SaúdeManguinhos, 17(2), 738-68. https://doi.org/ 10.1590/S0104-59702010000600031

Facchinetti, C., Cupello, P., \& Evangelista, D. F. (2010). Arquivos Brasileiros de Psiquiatria, Neurologia e Ciências Afins: uma fonte com muita história. História, Ciências, Saúde-Manguinhos, 17(2), 527-535. https://doi.org/10.1590/S0 104-59702010000600015
Huertas, R. (2017). Another story for another Psychiatry. Barcelona: Xoroi Edicions.

Jacobina, R. R., \& Gelman, E. A. (2008). Juliano Moreira e a Gazeta Médica da Bahia. História, Ciências, SaúdeManguinhos, 15(4), 1077-1097. https://doi. org/10.1590/S0104-59702008000400011.

Jacó-Vilela, A. M., \& Silva, V. P. (2016). Medición psicológica en Brasil: la recepción particular de las técnicas de evaluación. In R. Mardones (Ed.), Historia local de la psicología. Discusiones teóricas, metodologicas y experiencias de investigación (pp. 320-334). Santiago de Chile: Ediciones Universidad Santo Tomás-RIL Editores

Jacó-Vilela, A. M. (2012). História da Psicologia no Brasil: uma narrativa por meio de seu ensino. Psicologia: Ciência e Profissão, 32 (spe), 28-43. https://doi.org/10.1590/S14 14-98932012000500004

Jacó-Vilela, A. M. (2014). Psychological Measurement in Brazil in the 1920s and 1930s. History of Psychology, 17(3), 237-248. https://doi.org/10.1037/a0035333.

Kehl, R. (1941). A psicologia da personalidade-guia de orientação psicológica. Rio de Janeiro: Francisco Alves.

Klappenbach, H. (2006). Recepção da Psicologia Alemã e Francesa pela Jovem Psicologia Argentina. Mnemosine. Psicologia e Historia, 2(1), 75-86. Retrived from http://mnemosine.com.br/ojs/index.p hp/mnemosine/article/viewFile/85/pdf_71.

LBHM. (1925). Editorial. Archivos Brasileiros de Hygiene Mental, 1(1). Retrieved from

LBHM. (1930). Psychologia e Hygiene MentalEditorial. Archivos Brasileiros de Hygiene Mental, 3(9), 311-312.

Law 5168. (1927, 13 de janeiro). Crêa a arma de Aviação do Exercito [Create the army aviation weapon]. Diário Oficial da União, seção 1. http://www2.camara.leg.br/legin/fed/lei/ 1920-1929/lei-5168-13-janeiro-1927-5630 56-publicacaooriginal-87165-pl.html

Leme Lopes, M. B. (1930). Pesquisas sobre a memória de fixação [Surveys on fixing 
memory]. Archivos Brasileiros de Higiene Mental, 3, 235-240.

Leme Lopes, M. B. (1932). A attenção concentrada explorada pelo test de cancellamento [Concentrated attention explored by cancelling test]. Archivos Brasileiros de Higiene Mental, 5, 41-63.

Leme Lopes, M. B., \& Fialho, I. A. (1929). Suggestões para o emprego dos tests [Suggestions for the application of the tests]. Archivos Brasileiros de Hygiene Mental, 2, 68-77.

Lobato, J. B. M. (1956). Mr. Slang e o Brasil e o problema vital. São Paulo: Brasiliense..

Lopes, E. (1925). Actas da sessão de assemblea geral ordinária realizada em 28 de fevereiro de 1925. Archivos Brasileiros de Hygiene Mental, 1(1), 209-221.

Lourenço Filho, M. B. (2004). A Psicologia no Brasil. In M. A. M. Antunes (Ed.), História da Psicologia no Brasil: primeiros ensaios [History of Psychology in Brazil: first trials] (pp. 71-108). Rio de Janeiro: EdUERJ/CFP. Mathias, C. M. (2017). O Pavilhão de Observação na psiquiatria do Distrito Federal: a gestão de Henrique Roxo (1921-1945) [The role of the Observation Pavilion in Psychiatry in the Federal District: the management of Henrique Roxo (1921-1945)]. Dissertação (Mestrado em História das Ciências e da Saúde). Casa de Oswaldo Cruz, Rio de Janeiro.

Medeiros, M. (1908). A questão dos métodos em psicologia [The problem of methods in Psychology]. Archivos Brasileiros de Psychiatria, Neurologia e Medicina Legal, (1-2), 23-51.

Meyer, M. (2017). Reasoning against Madness Psychiatry and the State in Rio de Janeiro, 1830-1944. New York, NY: University of Rochester Press.

Moreira, J. (1902a). Da necessidade da fundação de laboratórios nos hospitais. Gazeta Médica da Bahia, (33), 439-450.

Moreira, J. (1902b). O asilo-colônia de Alienados em Juqueri (S. Paulo). Gazeta Médica da Bahia, (33), 399-407.
Moreira, J. (1907). Moléstias mentais. Archivos Brasileiros de Psychiatria, Neurologia e Sciencias Affins, 3(1), 101-105.

Moreira J. (1922). A luta contra as degenerações nervosas e mentais no Brasil (communication presented at the National Congress of Practices).Brasil Médico, 2, 225-226.

Moreira, J. (1925). A selecção individual de immigrantes no programma da hygiene mental. Archivos Brasileiros de Hygiene Mental, 1, 109-15.

Mulberger, A. (2014). The need for contextual approaches to the history of mental testing. History of Psychology, 17(3), 177-186. https: //doi.org/10.1037/a0037487

Mulberger, A. (2017). Mental association: testing individual differences before Binet. Journal of the History of the Behavioral Sciences, 53(2), 176-198. https://doi.org/10.1002/jhb s. 21850

Muñoz, P. F. N. (2015). À Luz do Biológico: psiquiatria, neurologia e eugenia nas relações Brasil-Alemanha (1900-1942) (Doctoral dissertation). Fundação Oswaldo Cruz, Rio de Janeiro. https://www.arca.fiocruz.br/han dle/icict/17721

Oda, A. M. G. R. (2000). Nina Rodrigues e a loucura epidêmica de Canudos. Revista Latinoamericana de Psicopatologia Fundamental, 3(2), 139-44. https://doi.org/ $10.1590 / 1415-47142000002009$

Oliveira, E. (2004). Engenho de Dentro do lado de fora: território comum com um engenho novo (Monograph). Fundação João Goulart, Rio de Janeiro.

Peixoto, A. (1905). Relatório apresentado ao Exm. Sr. Dr. S. S. Seabra, Ministro da Justiça e Negocio Interiores, pelo Dr. Afrânio Peixoto, director interino do hospício Nacional de Alienados, 1904-1905. Rio de Janeiro: Imprensa Nacional.

Penna, A. G. (1989). Acerca dos psicólogoseducadores na cidade do Rio de Janeiro: Manoel Bomfim, Maurício Campos de Medeiros, Plínio Olinto e Lourenço Filho [About psychologistseducators in the city of Rio de

| Universitas Psychologica | V. I8 | No.5 | 2019 | 
Janeiro: Manoel Bomfim, Maurício Campos de Medeiros, Plínio Olinto and Lourenço Filho]. Forum educacional, 13(3), 7-34. http://bibliotecadigital.fgv.br/ojs/inde x.php/fe/article/viewFile/61049/59269

Pires, N. (1951). Relatório sobre o I Congresso Internacional de Psiquiatria. Neurobiologia, 14(2), 134-145.

Pires, W., \& Luz, C. (1931). O liquor após malarioterapia. Anais da Assistencia a Psicopatas, (1), 3-12.

Porto-Carrero, J. P. (1933). Psicanálise de uma civilização. Rio de Janeiro: Guanabara, Waissman-Koogan Ltda.

Portocarrero, V. (2002). Arquivos da loucura: Juliano Moreira e a descontinuidade histórica da psiquiatria. Rio de Janeiro: Fiocruz. https ://doi.org/10.7476/9788575413883

Radecki, W. (1928/1929). Tratado de Psicologia [Treaty of Psychology]. Rio de Janeiro: Escola de Serviço Social do Exército

Radecki, W. (1925). Hygiene mental da creança, baseada sobre as leis da psychologia [Children's mental hygiene, based on the laws of psychology]. Archivos Brasileiros de Higiene Mental, 1(1), 11-89.

Radecki, W., \& Radecka, H. (1925). Pesquizas experimentaes sobre a fadiga dos menores trabalhadores nas fábricas. Nota prévia. Archivos Brasileiros de Higiene Mental, 1 (2), 181-184.http://old.ppi.uem.br/gephe/ index.php/arquivos-digitalizados/14-sampl e-data-articles/85-arquivos-brasileiros-de-h igiene-mental.

Ramos, F. A. G., \& Geremias, L. (2014). Instituto Philippe Pinel: origens históricas. http://www.sms.rio.rj.gov.br/pine 1/media/pinel_origens.pdf.

Reis, J. R. F. (2000). De pequenino é que se torce o pepino: a infância nos programas eugênicos da Liga Brasileira de Higiene Mental. Hist. ciênc. saúde-Manguinhos, 7(1), 135-157. https://doi.org/10.1590/S0104-59 702000000200007

Riedel, G. (1925). Acta da sessão do conselho executivo. Actas e trabalhos da Liga Brasileira de Hygiene Mental. Archivos Brasileiros de Hygiene Mental, 1(1),
209-21. http://old.ppi.uem.br/gephe/ABH M/ABHMAno1N11925.pdf

Rinke, S. (1996). 'Der Letzte Freie Kontinent': Deutsche Lateinamerikapolitik im Zeichen transnationaler Beziehungen, 1918-1933 (Vols. 1-2). Stuttgart: Hans Dieter Heinz..

Rodrigues, R. N. (1890). Os mestiços brasileiros [The Brazilian mestizos]. Rio de Janeiro: Brazil Medico.

Rose, N. (1996). Inventing our selves. Cambridge: Cambridge University Press. https://doi.org /10.1017/CBO9780511752179

Roxo, H. B. B. (1901). Duração dos atos psíquicos elementares nos alienados [Duration of elementary psychic acts in the alienated ones] (Doctoral dissertation). Faculdade de Medicina do Rio de Janeiro, Rio de Janeiro.

Roxo, H. B. B. (1938). Manual de Psychiatria [Psychiatry Handbook]. Rio de Janeiro: Livraria Francisco Alves.

Russo, J. A. (2005). Julio Porto Carrero: a psicanálise enquanto processo civilizador. In J. A. Russo, L.F. D. Duarte \& A. T. Venancio (Eds.), Psicologização no Brasil: atores e autores (pp. 125-137). Rio de Janeiro: Contracapa.

Saturnino, M. (1930). Psychometria de 100 soldados pelos tests de Binet. Archivos Brasileiros de Hygiene Mental, 3(1), 12-17.

Shamdasani, S. (2005). 'Psychotherapy': the invention of a word. History of Human Sciences, 18(1), 1-25. https://doi.org/10.117 $7 / 0952695105051123$

Silva, S. S. A. (2012). Iluminismo e ciência luso-brasileira: uma semiologia das doenças nervosas no período joanino (Doctoral dissertation). Fundação Oswaldo Cruz, Rio de Janeiro. https://www.arca.fiocruz.br/han dle/icict/19961.

Sousa, R. P., Porto, F., \& Trigueiro, K. F. (2019). Colônia de alienadas do Engenho de Dentro: Caracterização das internas (1921-1927). Nursing (Säo Paulo), 22 (251), 2875-2879.

Stubbe, H. (2015). Sigmund Freud in den Tropen-DasAbenteuer1 der fru\#hen Psychoanalyse (1914) in Brasilien. In C. Santos-Stubbe, P. Theiss-Abendroth \& H. 
Stubbe (Orgs), Psychoanalyse in Brasilien (pp. 15-58). Giessen: Psychosozial-Verlag. h ttps://doi.org/10.30820/9783837969320-15

Venancio, A. T. A. (2011, December). From the agricultural colony to the hospital colony: configurations for psychiatric care in Brazil in the first half of the twentieth century. História, Ciências, Saúde-Manguinhos, 18(supl.1). https://doi. org/10.1590/S0104-59702011000500003

Wanderbroock Jr., D., \& Boarini, M. L. (2009). A educação sob medida: os testes psicológicos e o higienismo no Brasil (1914-45). Maringá: EdUEM.

\section{Notes}

[1] Decree 206, of 1890, established an agency known as Medical and Legal Assistance for the Insane (Assistência Médica e Legal de Alienados), which served only the federal capital. In 1927, the agency was renamed as Assistance for Psychopaths (Assistência a Psicopatas), and it began serving not only the insane but all who presented some risk of suffering from a mental disorder. The agency pushes for nationwide standardized models of practices, classifications, and institutions until 1941, when it was restructured as the National Mental Illness Service (Serviço Nacional de Doenças Mentais; 1941-1970) (Fabricio, 2009).

[2] The National Hospice for the Insane was the first specialized institution for the mentally ill in Latin America. During the Empire, it was known as Pedro II Hospice (Hospício Pedro II; 1852-1889). After the Proclamation of the Republic, it was renamed the National Hospice for the Insane (Hospício Nacional de Alienados; 1889-1911). The 1911 reform renamed it the National Hospital for the Insane (Hospital Nacional de Alienados; 1911-1927). Under a further reform, it became the National Hospital for Psychopaths (Hospital Nacional de Psicopatas; 1927-1944), which was how it was known until it closed in the 1940s (Facchinetti, 2011, pp. 250-252).

[3] The Engenho de Dentro Colony (Colônia de Engenho de Dentro) was founded in 1911 to receive the overflow of indigent women from the HNA. In 1935, it expanded and transformed into the Gustavo Riedel Colony for Psychopaths (Colônia de Psicopatas
Gustavo Riedel). In 1944 it replaced the HNA itself, now under the name National Psychiatric Center (Centro Psiquiátrico Nacional). (Facchinetti, Ribeiro, Chagas, \& Reis, 2010)

[4] Good exceptions to it are Rose's book, on different uses of psychological tests (Rose, 1996) and Anette Mulberger's work (see, for example, Mulberger, 2014; 2017). In 2014, the journal History of Psychology published a special issue on the topic as well. This work follows this historiographical tradition for the development of this narrative.

[5] Until the $19^{\text {th }}$ century, the only studies offered in Brazil were the theology and philosophy courses at Catholic seminaries. The 1808 arrival of Emperor João VI and the Portuguese Court fostered the establishment of higher education courses in both medicine and law, in Bahia and Rio de Janeiro. In 1832, these courses were transformed into fullfledged institutes of higher learning. From that date on, attending college was prerequisite to becoming a doctor; students finalized these studies by writing a thesis, which was evaluated by a committee of professors.

[6] Male and female inmates who were confined to the hospital were assigned to the Calmeil and Morel wards, respectively. The Indigents Pavilion, which was tremendously overcrowded, was also divided into a ward for men, called Pinel, and one for women, called Esquirol (Meyer, 2017).

[7] The new pavilions created were: Bourneville, for children; Sigaud and De-Simoni, both for tuberculosis sufferers; and Márcio Nery, for sufferers of Hansen's disease. Later, the HNA campus came to include a ward for the criminal insane, the Lombroso Ward and a Military Pavilion, named Nina Rodrigues (Facchinetti et al., 2010).

[8] In his thesis, Roxo explained that he used this instrument just because it was available at the Nervous Disease Clinic, which shows us the existence of experimental psychology instruments in the HNA.

[9] In HNA annual reports of the years 1904 and 1905 , is informed that Manoel Bonfim (1868-1932), director of the Pedagogium Experimental Psychology Laboratory, was consulted in order to determine the materials to be purchased by the hospital: Mosso, Summer, Titchener, Kraepelin, Binet, Toulouse, etc. (Peixoto, 1905, p. 40). 
[10] Gustavo Riedel (1887-1934) was responsible for the foundation of the League in 1922. Riedel (1925: 210) stated that he had been entrusted by none other than Clifford W. Beers (1876-1943) - father of the mental hygiene movement-with establishing "the first Social Medicine Association in South America." The following year, the league was recognized as a "public utility" and began receiving federal government subsidies.

[11] According to Centofanti (1982), Riedel obtained financial support from the Gaffrée Guinle Foundation, which ceded a few rooms for the Psychology Laboratory at one of its dispensaries.

[12] Waclaw Radecki (1887-1953) was a Polish psychologist with a doctorate from the Université de Genève, former head of the Psychology Laboratory at the Free Polish University, and former assistant to Edouard Claparède at the Institut Jean-Jacques Rousseau, where he devoted himself mainly to researching affectivity as the basis of perception, a theory he called "affective discriminationism". He came to Brazil after World War I and set up and head the Psychology Laboratory at the Engenho de Dentro Colony from 1924 to 1932. $\mathrm{He}$ proposed the establishment of a psychology institute, one of whose divisions would be a Higher School of Psychology (Escola Superior de Psicologia). The federal government accepted the proposal, but the institute was closed in 1932 under strong pressure from physicians and Catholics. Radecki left Brazil for Argentina and later Uruguay, where he established Uruguay's first psychology course. (Centofanti, 1982).

[*] Review article. 